\title{
IAMJ
}

INTERNATIONAL

AYURVEDIC

MEDICAL JOURNAL

\section{JALAUKAVACHARAN AND DIETARY INTERVENTION IN TWAKA VIKAR (VICHARCHIKA): A CASE STUDY}

\author{
Ramchandra P. Babar ${ }^{1}$, Shravani R. Babar ${ }^{2}$ \\ ${ }^{1}$ Associate Professor, Department of Kaumarbhritya, \\ ${ }^{2}$ Assistant Professor, Department of Swasthavritta and Yoga, \\ Sumatibhai Shah Ayurved Mahavidyalaya, Malwadi, Hadapsar, Pune 28., Maharashtra, India
}

Email: ramchandrababar@gmail.com

https://doi.org/10.46607/iamj0807342020

(Published online: July 2020)

Open Access

(C) International Ayurvedic Medical Journal, India 2020

Article Received: 08/06/2020 - Peer Reviewed: 21/06/2020 - Accepted for Publication: 01/07/2020

Check for updates

\begin{abstract}
Currently observed that the sedentary lifestyle and stressed work schedule has increased the number of skin disorders (Twaka Vikara). It has been established fact that the common cause of various skin disorders (Twaka Vikara) is altered Ahara and Vihara (Dietary and Lifestyle changes), specially Viruddhaahar (incompatible diet). Ancient Ayurveda Scholars described in detail Raktamokshana (the procedure of removing the vitiated blood) for the management of the diseases caused by Rakta and Pitta. The Jalaukavacharan (Leech therapy) is one of the effective Raktamokshan (bloodletting) management of vitiated Rakta and Pitta caused skin disorders. In Jalaukavacharan the anti-coagulant property of hirudin, contained in leech saliva, lead to wider therapeutic application in prevention and treatment of various Twaka vikara. Twaka Vikara (Vicharchika) is one of the mostly observed skin disease, which is mainly developed on account of misconduct in all aspect including kayik, vachik, manasik variety of misconducts along with dietary and lifestyle irregularities. Dietary intervention and lifestyle modification play an important role to cure the diseases. In Present case study Patient showing symptoms of Vicharchika (Twaka Vikara) having improper dietary habits and stressed work schedule, after the Dietary Regimen and lifestyle modification along with Jalaukavacharan at local area showed improvement in skin texture. The details of
\end{abstract}


the causative factors, clinical findings, improvements observed after implementation of preventive and curative management plans are presented here.

Keywords: Vicharchika, Twaka Vikara, Jalaukavacharan, Dietary intervention.

\section{INTRODUCTION}

Dietary and Lifestyle irregularities cause many diseases like Skin Disorders, Diabetes, Hypertension, Obesity, Cardiovascular Disorders etc. Ancient Scholars of Ayurveda described the Kushta is one of the chronic skin disease, which causes due to the faulty Dietary and Lifestyle changes like Viruddhahar (Incompatible Diet), Avyayama (less physical activities), Anidra (irregular sleep), Diva swap (Day sleep), Chinta (stress) and many more ${ }^{1}$. Vicharchika is one type of Kshudra Kushta in which Vitiated doshas mainly Kapha Dosha causes the dushti of Rasa, Rakta dhatu, affects skin; in which the blackish discoloration of skin, itching, dryness of skin and discharge are observed. ${ }^{2}$ The altered / faulty Dietary and Lifestyle habits causes Twaka vikara. So that avoidance of causative factors (Nidan Parivarjan) along with Dietary \& Lifestyle modification is an important treatment plan along with other medication.

Acharya Charaka explains the Shodhana (purification) and Shamana (pacifying) chikitsa for Kushtha (skin disorders), in which Raktamokshan (bloodletting) is one of Shodhana chikitsa for Pittapradhana $k u s h t h a^{3}$. Letting out impure blood with leech (Jalau$k a$ ), vein section, various instruments (Shrunga, Tumbi, etc.) from body is known as Raktamokshan ${ }^{4}$. Among shodhan karma for the various skin disorders, ancient Acharyas have frequently quoted that, Raktamokshan (bloodletting) is to be considered as the supreme method. Various methods and procedures are offered, which acts as blood purificatory process and hence useful in Rakta pradoshaj vyadhi like Kushtha. ${ }^{5,6}$

According to Modern Medicine skin disorders primarily of autoimmune kind, make the dermis thick with poor tissue perfusion. The leech saliva prevents inflammatory mediators, decrease tissue thickness, accelerate reperfusion $\&$ increase permeability of tissue making it more acceptable to therapeutics. It makes
Jalukavacharan an ideal mode of treatment in skin Disorders. $^{7}$

Aim: To study the effectiveness of Jalaukavacharan, diet and Lifestyle modification in Twaka Vikara (Vicharchika).

\section{Objectives:}

1. To observe the changes in skin after Jalaukavacharan in Vicharchika.

2. To observe the changes in skin after diet and lifestyle modification in Vicharchika.

\section{Material and Method:}

Case Report: A 29 years old, working Female, approached to OPD with following complaints:

1. Blackish discoloration of skin (on lateral side of ankle joint) since 3 months.

2. Itching sensation at the affected area: since 2 months.

3. Dryness of the affected area: since 2 months.

4. Discharge on/off from the affected area: since 1 month.

\section{Personal History:}

Hetusevan (Etiological factors): Details of the history was taken and found the etiological factors as follow

Aharaj Hetu: Milk and milk products, curd, Sweet products, Pickle, Ice cream, oily foods, papad etc. Guru (Paneer, Curd), Ushna, Tikshna, spicy food was in the diet regularly.

Viharaj Hetu: Lack of exercise / physical inactivity, inadequate sleep.

Manasa hetu: Stress, depression.

Past History: There was no previous history of any allergy/ Systemic Disorder/ Skin Diseases.

Family History: No family history of skin diseases. Present History:

Patient was well 3 months before, then she started the Itching sensation at the lateral side of B/L Ankle joint, then there was redness at affected area, after that there 
was dryness of skin, blackish lesions were appeared and sometimes also having discharge from that lesions, She was on anti-itching oral medicine and local cream application earlier, but not get the relief.

The patient came to OPD with all the above complaints and signs/symptoms. After all the clinical examination and history, the patient was recruited for

Table 1: Ashtavidha Pariksha:

\begin{tabular}{|l|}
\hline Nadi: $76 /$ min \\
\hline Mala: Baddhata \\
\hline Jivha: Alpakrut \\
\hline
\end{tabular}

Local Examination:

- Blackish lesions over B/L outer side of ankle joint.
Dietary and Lifestyle Modifications along with Jalukavacharana.

On Examination (O/E): Afebrile, Pallor: +, Pulse - 76/min Blood Pressure - 120/80mmHg RS: AEEBS,

CVS: S1, S2 (N) NAD

$\mathrm{P} / \mathrm{A}-\mathrm{Soft}$, bowel habit was regular.

CNS: Conscious, Oriented.

\section{Samprapti Ghatak:}

Table 2: Samprapti Ghatakas ${ }^{8}$

\begin{tabular}{|l|l|}
\hline Dosha: & Kapha- Kledaka, Pitta- Pachaka, Ranjak, Bhrajak, Vata-Samana, Vyana. \\
\hline Dushya: & Rasa, Rakta, Mamsa and Shat-Tvacha, Lasika \\
\hline Agni: & Jatharagni, Bhutagni, Rasa, Rakta and Mamsa dhatvagni \\
\hline Srotasa: & Rasavah, Raktavah, Mamsavah, Swedavaha Srotasa \\
\hline Srotodushti: & Sanga (Margavarodha). \\
\hline Adhisthana: & Tvacha \\
\hline Udbhavasthana: & Amashaya, Rasa-Raktadi dhatu \\
\hline Prasara: & Rasayani \\
\hline Roga Marga: & Bahya \\
\hline Vyakti Sthana: & Gulpha pradeshasth Tvacha \\
\hline Upadrava: & Kandu \\
\hline
\end{tabular}

\section{Treatment Planed: ${ }^{7}$}

1. Jalaukavacharan (Leech application) at local affected skin area: weekly for 2 weeks.

2. Intervention with Dietary and Lifestyle modifications

\section{Dietary Restrictions:}

- Avoid Dahi and its combinations with foods i.e. Dahi Vada, Custered etc

- Hot, Oily, Spicy food (Pizza, Burger, Vada-Paav, Misal etc.)

- Bakery products (Bread, Biscuits, Khari, Toast, Cake, Pastries)

- Virudhahar (Fruits \& milk combinations together like custard, milk shakes).
Shabda: Spashta

Sparsha: Ishat Ushna

Druk: Prakrut

Akruti: Madhyam

- Ruksha (dryness) +++

- Khara++
- Milk and milk products (Paneer, Basundi, Pedha, Lassi etc.)

Diet Advice ${ }^{7}$

- Laghu and Supachya Ahara.

- Godhum, Tandul, Mudga, Masoor (1year old).

- Some Vegetables: Karvellak, Padval, Garlic, Chakavat, Vruntak.

- Use Kulith.

- Yavagu Sevan.

- Sunthi sidha jala.

Lifestyle Advice \& Restriction: ${ }^{9}$

- Vyayama /Regular Exercise (Brisk Walking, Skipping, Stepping) 
- Pranayama and Meditation (Anulom-Vilom, Brhamari, 'Om' Chanting)

- Avoid day sleep (Diwaswap), late getting up from bed in the morning, late night sleep, lying down after meal.

Pathophysiology and treatment plan ${ }^{10}$ :

Hetusevana (Virudha Ahar, Guru, Snigdha, drava padartha sevan, Vegavidharana, Aniyamita Nidra)

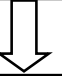

Tridosha Prakopa (Kapha dosha Pradhanya)

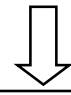

Rasa, Rakta, Mansa, Twaka dushti

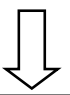

Discoloration of skin, Dryness of skin, Itching and Discharge from, infected area.
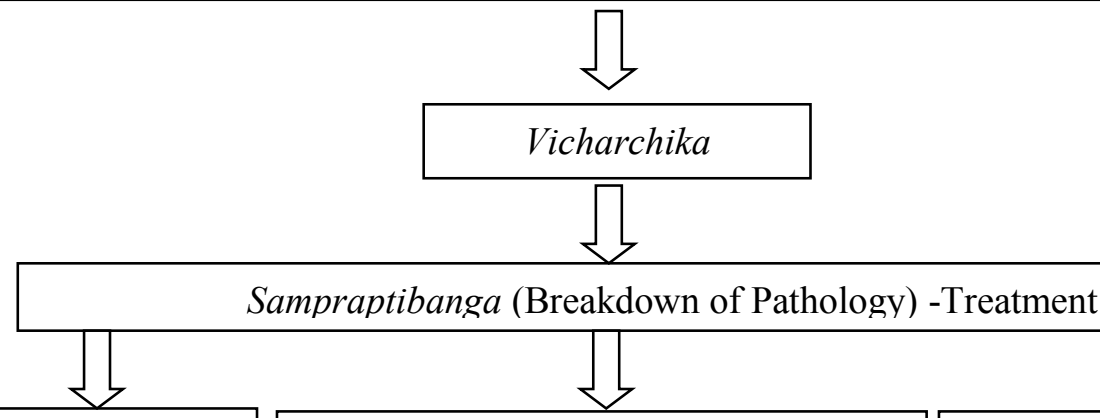

\section{Jalaukavachara}

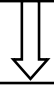

Removes all vitiated blood<smiles>[C]=C</smiles>

Decreases Rakta Dushti Acts as Pittaghna

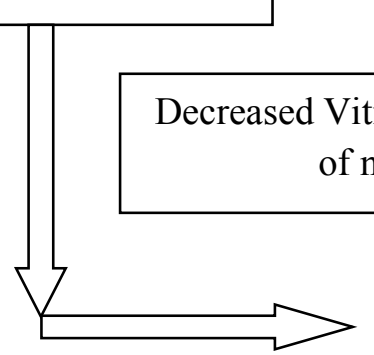

1. Laghu- Supachya Ahar.

2. Yavagu

3. Sunthisiddha Jala.

Decrease the Kleda, srotoshodhan

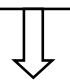

Vitiated Tridosha and regulate the formation of normal Dhatu/upadhatu/tvacha.

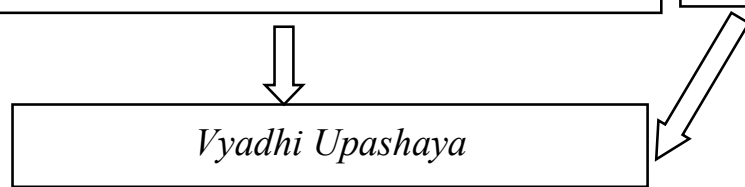

Lifestyle Modification

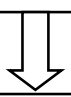

1. Vyayama/physical activity.

2. Pranayama/meditation

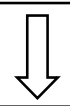

Mental Relaxation, subside stress

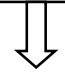

Proper Rasadhatu formation and other Dhatu Poshan 


\section{OBSERVATION:}

Table 3: clinical findings before and after treatment

\begin{tabular}{|l|l|l|l|}
\hline & Symptoms & Before Treatment & After Treatment \\
\hline Shyav twaka Vaivarnya & Blackish Discoloration of Skin & +++ & + \\
\hline Rukshakata & Itching & +++ & Complete Relief \\
\hline Strava & Dryness of Skin & +++ & Complete relief \\
\hline
\end{tabular}

(Gradation of symptoms: Mild - + Moderate -++ Severe -+++ )

\section{DISCUSSION}

Twaka Vikaras are commonly occurs due to faulty Dietary habits and altered lifestyle. As diet and lifestyle affects the digestion \& metabolism, proper $R a$ sadi dhatu formation, end tissue nourishment and formation. Skin (Tvacha) represents the quality Rasa dhatu, also Tvacha is upadhatu of the Mamsadhatu. So, for healthy skin the healthy/quality formation of Rasa, Rakta, Mamsa and shat-tvacha is needed ${ }^{11}$. Quality of Ahararasa/ Rasa dhatu formation helps information of Rakta, Mamsa, uttarottar dhatus, as it nourishes the later ${ }^{12}$. Bhrajak pitta reflects in skin, depends on the quality of pitta/Pachak pitta. Pitta and Rakta have ashrayashrayi sambandha (one depends on other), vitiation of one affects the other ${ }^{13}$. So Raktamokshan is planned in many Pittaj/Raktaj disorders. Shat-tvachas are the updhatu of Mamssadhatu, quality of Mamsa depends on the quality formation of the Ahar-rasa, Rasa, Rakta dhatu. So that there is importance of quality diet, quality Ahar rasa, uttarottar dhatu formation in the healthy skin. The altered mental states (Manasik Avasthas - Chintan, etc) causes the vitiation of the Rasa dhatu, so on various disease formations ${ }^{14}$. So, management of the mental stress/ various mental disorders is also needed for healthy skin life.

In the above case, the patient was suffering from the Vicharchika due to faulty dietary habits like milk and milk products, sweets, junk foods which all are Guru, Ushna, Snigdha guna; also having the habits of $A n$ idra, Ratri jagaran and divaswap which aggravated the Tridoshas, and formation of Kleda, leads to the Rasa, Raskta, Mansa dhatu dushti, leads to the Twakdushti. ${ }^{15}$
With in-detail history and clinical examination, the management plan recruited was Jaiukavacharan as the locally pitta/rakta dushti, kled formation and strotorodha was present. Jaluka application removes the dushita rakta (affected blood) and strotasavrodh (obstruction in the circulatory channels), and then $R a$ sa, Rakta Dhatu circulation normalises. ${ }^{16}$ For the systemic involvement of Doshas and dhatus, the Dietary and Lifestyle modifications were advised. Proper diet and physical activity helps in the proper nourishment of body elements with healthy tissue formation. Sunthisiddha jala which decreases aggravated/vitiated doshas, helps in modification of digestive power/metabolism at GI/Tissue/cellular level (Agnideepa$n a$ ), decreases kleda/Aam, remove the Strotasavrodh, helps in quality of Rasa/Rakta dhatu circulation, proper nourishment at tissue level and healthy tissue formation.

Pitta Shodhan: vitiated pitta gets removed by $\mathrm{Ja}$ laukavacharan, as Pitta and Rakta are Ashrayashrayi sambandha (Rakta is seat of Pitta). As Jalauka is Sheet in nature, pacifies the ushna, tikshna guna of pitta. Also, the dietary modification \& physical activities help to normalise the vitiated doshas. Liver and spleen get stimulated so that quality of Rakta dhatu formation occurs which reflects in Teja / Prabha of the kanti / Tvaka. ${ }^{15}$

Psychological symptoms also get decreased with the help of Pranayama practices and patient gets complete relief from the stress. Pranayam/Yoga helps in reducing stress/ chinta results in proper quality Ahararasa/ Rasa-Rakta dhatu formation, which helps in healthy skin tissue formation. ${ }^{17}$

So, after the implementation of the above management plan (Jalaukavacharan along with dietary \& 
lifestyle interventions) the aggravated Doshas, malformed Dhatus gets decreased, and formation of healthy skin tissue with its luster occurs. So, it is observed that the dietary habit and lifestyle modification along with Jalaukavacharan is effective to cure Vicharchika.

\section{CONCLUSION}

Dietary and Lifestyle modification along with Jalukavacharan should be taken in consideration while treating the patients of Vicharchika / skin disorders, as present case study showed significant results in reducing the signs and symptoms of Vicharchika. In Twak Vikara, we observe the psychological factors which also aggravate the disease, so Counseling, Pranaya$m a$, Physical activity has significant role, while dealing with the psychological factors of skin diseases.

\section{REFERENCES}

1. Vd. Satyanarayana sastri, Charak samhita of Agnivesha, Revised by Charak and Drdhabala, Publish by Chaukhambha Bharati Academy Varanasi in 2002, Ch. Chi. 7/4-5, Page no 248.

2. Vd. Satyanarayana sastri, Charak samhita of Agnivesha, Revised by Charak and Drdhabala, Publish by Chaukhambha Bharati Academy Varanasi in 2002, Ch. Chi. 7/23, Page no 252.

3. Vd. Satyanarayana sastri, Charak samhita of Agnivesha, Revised by Charak and Drdhabala, Publish by Chaukhambha Bharati Academy Varanasi in 2002, Ch. Chi. 7/39, Page no 255.

4. Dr Vasant Patil, Principles and Practice of Pancakarma, Atrey Ayurved Publication, Ilkal, Bagalkot, ISBN 97881-910286-0-7; page 528
5. Agnivesh, Caraksamhita of Agnivesh, Chaukhambha Surbharati Prakashan, Varanasi published 2008, Sutrasthan 24/18; Chikitsasthan7/39.

6. Vd Yadavaji Trikamji Acharya, Susrutsamhita of Susruta, Chaukhambha Orientalia publication, Varanasi, 5th Edn 1992, Chikitsasthan 9/6,43.

7. Vd Y G Joshi, Kayachikitsa, Pune Sahitya Vitaran Publication, Pune 30, $4^{\text {th }}$ Edn 2001, Chapter13/page207.

8. Vd Y G Joshi, Kayachikitsa, Pune Sahitya Vitaran Publication, Pune 30, $4^{\text {th }}$ Edn 2001, Chapter13/page193.

9. Agnivesh, Caraksamhita of Agnivesh, Chaukhambha Surbharati Prakashan, Varanasi published 2008, Chikitsasthan7/3-6.

10. Agnivesh, Caraksamhita of Agnivesh, Chaukhambha Surbharati Prakashan, Varanasi published 2008, Chikitsasthan7/29-30, 37-40.

11. Agnivesh, Caraksamhita of Agnivesh, Chaukhambha Surbharati Prakashan, Varanasi published 2008, Chikitsasthan7/7-8.

12. Dr G K Garde, Sarth Vagbhat, Anmol Prakashan, $\mathrm{Pu}-$ ne02, $1^{\text {st }}$ Edn Reprint 2004, Sutrasthan 11/34-35, page 54.

13. Dr G K Garde, Sarth Vagbhat, Anmol Prakashan, Pune02, $1^{\text {st }}$ Edn Reprint 2004, Sutrasthan 12/10-14, page55.

14. Vd Y G Joshi, Kayachikitsa, Pune Sahitya Vitaran Publication, Pune 30, $4^{\text {th }}$ Edn 2001, Chapter2/page25.

15. Vd Y G Joshi, Kayachikitsa, Pune Sahitya Vitaran Publication, Pune 30, $4^{\text {th }}$ Edn 2001, Chapter13/page207.

16. Dr Vasant Patil, Principle and Practice of Panchkarma, Atreya Ayurved Publication, Ilkal, Bagalkot, ISBN 978-81-910286-0-7, page565-566.

17. Dr G K Garde, Sarth Vagbhat, Anmol Prakashan, $\mathrm{Pu}-$ ne02, $1^{\text {st }}$ Edn Reprint 2004, Chikitsasthan 19/98, page 322 . 
Picture 1: Skin presentation before and after the treatment

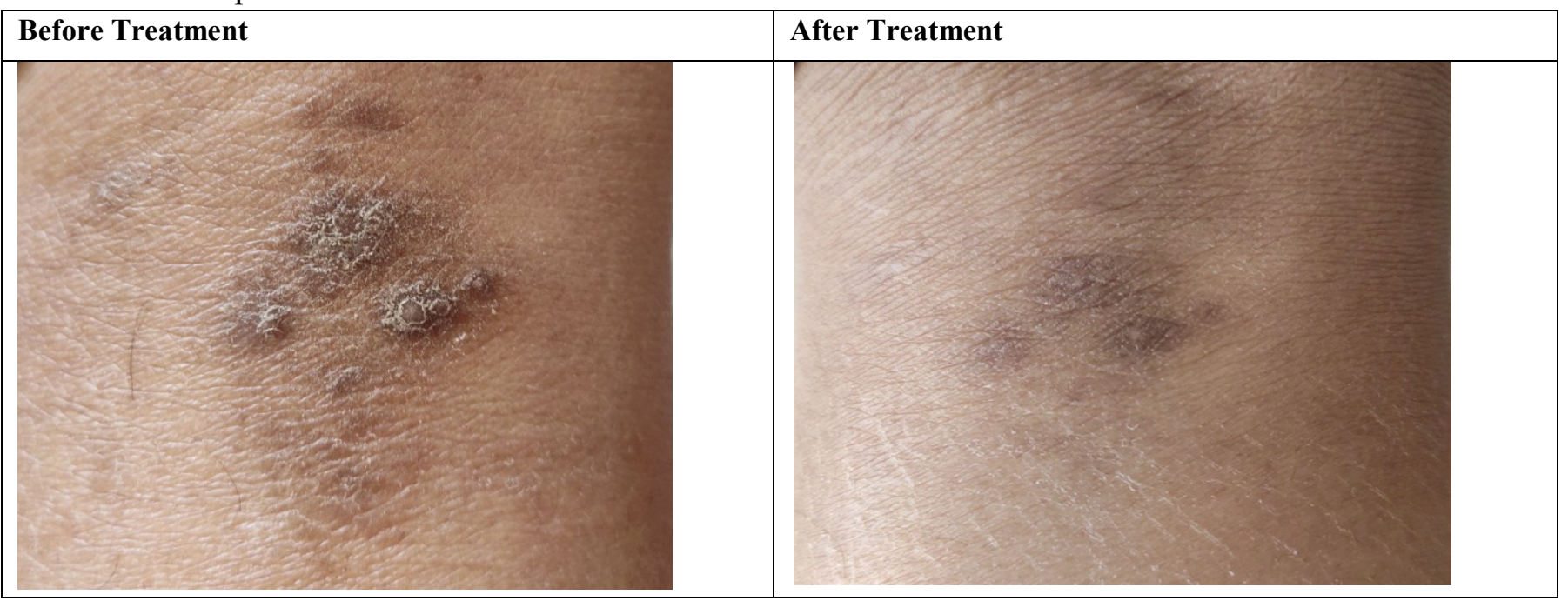

Picture 2: Jalaukavachan Karm (Leech therapy) on affected skin area

\begin{tabular}{|l|l|l|}
\hline During Jalukavacharana & \\
8 & &
\end{tabular}

\section{Source of Support: Nil \\ Conflict of Interest: None Declared}

How to cite this URL: Ramchandra P. Babar \& Shravani R. Babar: Jalaukavacharan And Dietary Intervention In Twaka Vikar (Vicharchika): A Case Study. International Ayurvedic Medical Journal \{online\} 2020 \{cited July, 2020\} Available from: http://www.iamj.in/posts/images/upload/4025_4031.pdf 